\title{
Estimating the Prevalence and Risk Factors of Obstetric Fistula in Ethiopia: Results from Demographic and Health Survey
}

\author{
Getnet Gedefaw (D) \\ Adam Wondmieneh (iD) ${ }^{2}$ \\ Addisu Getie ${ }^{2}$ \\ Melaku Bimerew (iD ${ }^{2}$ \\ Asmamaw Demis (iD ${ }^{2}$ \\ 'School of Midwifery, College of Health \\ Sciences, Woldia University, Woldia, \\ Ethiopia; ${ }^{2}$ School of Nursing, College of \\ Health Sciences, Woldia University, \\ Woldia, Ethiopia
}

\begin{abstract}
Introduction: Obstetric fistula is the most common obstetric problem in low- and middleincome countries where maternal care is inaccessible. Obstetric fistula has serious social and economic consequences resulting in devastating health problems for women. There is a lack of national studies that show the burden of obstetric fistula and risk factors; as a result, this study aimed to estimate the prevalence of obstetric fistula, its symptoms, and risk factors in Ethiopia.
\end{abstract}

Methods: A population-level cross-sectional study was conducted with a total of 7590 women who gave birth in the last 5 years, using data from the 2016 Ethiopian Demographic and Health Survey. Complex sample analysis and normalized weighting were used to compensate for the disproportionate sampling in the survey. A multivariable logistic regression model was fitted to find a significant association between obstetric fistula and covariates Both odds ratios (crude and adjusted) with their corresponding 95\% confidence intervals (CI) were reported.

Results: Among the 7590 women having given birth in the last 5 years, $32(0.42 \%)$ women with obstetric fistula were identified. Of these, $64 \%$ developed obstetric fistula after live birth and $23.1 \%$ developed obstetric fistula after stillbirth. More than $72.8 \%$ were associated with prolonged and very difficult labor. No history of contraceptive use (AOR $=3.43 ; 95 \% \mathrm{CI}$ : $1.05-11.21$ ), having a big problem of distance from the health facility (AOR $=3.7 ; 95 \% \mathrm{CI}$ : $1.05-11.21)$, early marriage $(\mathrm{AOR}=1.52 ; 95 \% \mathrm{CI}: 1.12-3.5)$, and being a rural resident $(\mathrm{AOR}=1.5 ; 95 \% \mathrm{CI}: 1.2-5.05)$ were risk factors associated with obstetric fistula.

Conclusion: This study finding revealed that obstetric fistula is the most common devastating obstetric problem in Ethiopia. Early marriage, early initiation of sexual intercourse, distance from the health facility, no history of contraceptive use, and rural residence were the predisposing factors to develop an obstetric fistula. Thus, interventions should focus on creating community awareness regarding early marriage and its consequences, early seeking of health facility visiting, and avoiding unintended pregnancy to minimize the subsequent complications.

Keywords: obstetric fistula, vaginal fistula, risk factors, Ethiopia

\section{Introduction}

Obstetric fistula is an abnormal connection between a woman's genital tract and the urinary tract (vesicovaginal fistula) or between the genital tract and the rectum (rectovaginal fistula), predominantly resulting from obstructed labor. Globally, the prevalence of obstetric fistula is nearly 2 million with an estimated incidence of 50,000-100,000 new cases registered each year. ${ }^{1,2}$ In sub-Saharan Africa 30,000
Correspondence: Getnet Gedefaw Email gedefawget@gmail.com 
130,000 new fistula cases were recognized and registered per year. Women who experience obstetric fistula suffer constant incontinence, shame, social segregation, and health problems. It is estimated that more than 2 million young women live with untreated obstetric fistula in Asia and sub-Saharan Africa. ${ }^{25}$

Obstetric fistula is a complication of childbirth existing nearly solely in low- and middle-income countries and results from prolonged and obstructed labor. It causes substantial grief for the affected women, the continual leakage leads to co-morbidities, and women become ostracized and shunned by their community due to incontinence of urine and/or stool. Women with obstetric fistula encounter health, psychological, and social consequences that are not completely resolved by repairing the fistula.,

In low and middle-income countries, limited obstetric care due to shortage of resources, and poor childhood nutrition in development, are associated with obstructed and prolonged labor resulting in downward pressure of the baby's head on the mother's pelvis. This leads to damage of tissue in the birth canal which can cause necrotizing of the tissue, thus creating an abnormal communication between organs i.e. obstetric fistula. Whereas, in high-income countries, the cause of obstetric fistula is likely due to iatrogenic causes, such as radiation therapy and any pelvic surgical interventions. ${ }^{5,6}$

Even though the number of new cases registered every year is more than 3000, around 1447 fistula cases were repaired in all treatment centers of Ethiopia. ${ }^{7}$

Various studies have reported that being a rural resident, not having attended formal education, not attending antenatal care, no skilled birth attendants, poor healthseeking behavior, poor referral systems, and transportation network, inadequate facilities providing comprehensive obstetric care services, poverty, malnutrition, lack of education, early marriage and childbirth, maternal age, number of births, harmful traditional practices, sexual violence, and lack of good quality or accessible maternal and health care were the contributing factors of obstetric fistula. ${ }^{8-10}$

Estimation of the burden of obstetric fistula in lowincome countries is still a challenge. Urgent action should be made to develop appropriate methods for measuring the national burden of obstetric fistula in order to understand the need for and to provide effective maternal health care. Moreover, the main aim of this study was to estimate the prevalence of obstetric fistula, its symptoms, and risk factors from a further population-level cross-sectional study using the 2016 Ethiopian Demographic and Health Survey. Furthermore, investigating the magnitude of obstetric fistula among reproductive-age women helps in planning to increase community awareness via delivering preventive strategies and opportunities against obstetric fistula at the health institution and community level.

\section{Methods and Materials}

\section{Study Area and Design}

This study was conducted in Ethiopia using the 2016 Ethiopian Demographic and Health Survey data, which were collected by the Central Statistical Agency (CSA), Ethiopia, and the DHS Program, ICF.

\section{Data and Sampling Procedures}

Data for this study were retrieved from the 2016 EDHS, which used a weighted multistage, stratified cluster sampling approach. The 2016 EDHS data employed a two-stage stratified cluster sampling procedure. These are stratification into urban and rural areas and secondly, a fixed number of households were selected systematically from the selected clusters. Then, all women aged 15-49 years in the selected households were included. Women who had a live birth in the last 5 years before the interview were included in this survey. A total of 15,683 women aged 15-49 years were interviewed in the 2016 EDHS, of which 7590 women had at least one live birth in the last 5 years before the survey; 8093 women were excluded from the study due to not having given birth in the 5-year period prior to the survey. Overall, the included sample size for this study was 7590 women who had at least one birth in the last 5 years before the survey, and women with known obstetric fistula in the last 5 years before the survey were excluded.

\section{Objectives}

Primary Objective

Estimating the prevalence of obstetric fistula.

\section{Secondary Objective}

Risk factors associated with obstetric fistula.

\section{Outcome}

Obstetric fistula among women who had at least one birth in the 5-year period prior to the survey.

\section{Experience of Obstetric Fistula: Having a Constant Leakage of Urine or Stool from the Vagina}

Obstetric fistula among women who had at least one birth in the 5-year period prior to the survey was the primary 
outcome of the study which coded as Not experienced obstetric fistula " 0 " and Experienced obstetric fistula " 1 ".

\section{Independent Factors}

\section{Socio-Demographic and Economic Factors}

Region, age at first marriage, age at first birth, age at first delivery, marital status, residence, educational status, employment status, and wealth index.

\section{Maternal, New-Born and Related Indicators}

Parity, place of delivery, the status of pregnancy, antenatal care, body mass index, sex of the neonate, the distance of health facility, and birth weight.

\section{Operational Definitions Household Wealth Quintile}

The wealth index classifications were in quintiles: poorest; poor; middle; rich; richest. These were computed using principal component analyses (PCA).

\section{Perceived Distance to Health Facility}

The responses for this variable were neither quantitative nor specific to services for delivery. The survey question asked women if the distance was a problem for them to get any medical help from health institutions, not limited to delivery care. The responses were coded as: "yes, big problem": or, "not a big problem". We used the same codes for the current study.

\section{Place of Residence}

This variable in the EDHS can explain the characteristics of the clusters directly. The two categories were: urban; rural.

\section{Data Processing and Analysis}

SPSS version 24 statistical software was used for analysis. A complex sample survey (stratified/clustered) sampling design was used to correctly calculate unequal probabilities of selection with weighted data. Rao-Scott chi-square has been employed to investigate the relationship between different predictors and experience of obstetric fistula through adjusting complex survey sampling. Multivariable binary logistic regression model was fitted to identify the association between explanatory variables and obstetric fistula.

Bivariable logistic regression has been employed to examine the association between obstetric fistula and its risk factors. Both descriptive and inferential statistics were used to present the findings of the study. Multicollinearity was checked to examine the correlation among independent variables. Model fitness was checked with Hosmer Lemeshow test. Finally, adjusted odds ratio (AOR) and crude odds ratio (COR) with its corresponding 95\% confidence intervals (CI) with a $p$-value $<0.05$ in multivariable logistic regression were used to declare the statistical association between obstetric fistula and risk factors.

\section{Results}

\section{Socio-Demographic and Economic Characteristics}

More than three-fourths of the study participants resided in rural parts of Ethiopia. Amongst the total study participants, $93.7 \%$ were in union/married. Regarding ethnicity, $41.2 \%$ of the women were Oromia ethnic group followed by Amhara 21.5\% (Table 1).

\section{Obstetrics and Related Characteristics}

From the overall study participants, $62.7 \%$ of the women had antenatal care follow-up. Regarding body mass index, $71.4 \%$ of the women had normal body mass index (Table 2).

\section{Characteristics of Patients with Obstetric Fistula}

From the total 7 patients who underwent an operation to fix their fistula, 4 of them were completely healed and the leakage was completely stopped. Out of 32 women having obstetric fistula, 21 of them suffered from obstetric fistula resulted during delivery of a baby and 20 of them were developed fistula due to obstructed and prolonged labor (Table 3).

\section{Risk Factors Associated with Obstetric Fistula}

In multivariable logistic regression, distance from the health facility, history of contraceptive utilization, age at first marriage, and residence were found to be significantly associated with obstetric fistula. The odds of experiencing obstetric fistula among women who had no contraceptive use were 3.43 times (95\% CI: 1.05-11.21) higher compared with women who had contraceptive use. Women who had a big problem of distance from the health facility had 3.7 times (95\% CI: 1.05-11.21) higher odds of experiencing obstetric fistula compared with their counterparts. Women who had early marriage were 1.52 times $(95 \% \mathrm{CI}$ : 1.12-3.5) more likely to develop obstetric fistula 
Table I Socio-Demographic and Economic Characteristics of Women Who Gave Birth in the Five Years Preceding the EDHS 2016, Ethiopia

\begin{tabular}{|c|c|c|}
\hline Variables & Frequency (N) & Percent (\%) \\
\hline \multicolumn{3}{|l|}{ Educational status of women } \\
\hline No education & 4791 & 63.1 \\
\hline Primary education & 2150 & 28.3 \\
\hline Secondary education & 429 & 5.5 \\
\hline Higher education & 230 & 3 \\
\hline \multicolumn{3}{|l|}{ Residence } \\
\hline Urban & 969 & 12.77 \\
\hline Rural & 6621 & 87.23 \\
\hline \multicolumn{3}{|l|}{ Marital status } \\
\hline Married & 7109 & 93.7 \\
\hline Single & 56 & 0.7 \\
\hline Widowed & 95 & 1.3 \\
\hline Divorced & 233 & 3.1 \\
\hline Separated & 97 & 1.3 \\
\hline \multicolumn{3}{|l|}{ Religion } \\
\hline Orthodox & 2882 & 38 \\
\hline Muslim & 2824 & 37.2 \\
\hline $\begin{array}{l}\text { Other (Protestant, Catholic, } \\
\text { Traditional) }\end{array}$ & 1884 & 24.8 \\
\hline \multicolumn{3}{|l|}{ Age at first birth } \\
\hline Below 15 years & 1101 & 15.4 \\
\hline $15-19$ years & 3698 & 51.6 \\
\hline $20-24$ years & 2216 & 30.9 \\
\hline 25 years and above & 156 & 2.2 \\
\hline \multicolumn{3}{|l|}{ Employment status } \\
\hline Currently working & 2172 & 28.6 \\
\hline Not currently working & 5418 & 71.4 \\
\hline \multicolumn{3}{|l|}{ Wealth index } \\
\hline Poorest & 1651 & 21.8 \\
\hline Poorer & 1654 & 21.8 \\
\hline Middle & 1588 & 20.9 \\
\hline Richer & 1427 & 18.8 \\
\hline Richest & 1269 & 16.7 \\
\hline \multicolumn{3}{|l|}{ Age at first marriage } \\
\hline Below 18 years & 5470 & 72.6 \\
\hline 18 years and above & 2064 & 27.4 \\
\hline \multicolumn{3}{|l|}{ Region } \\
\hline Amhara & 1632 & 21.5 \\
\hline Oromia & 3129 & 41.2 \\
\hline SNNPR & 1601 & 21.1 \\
\hline Tigray & 537 & 7.1 \\
\hline Harari & 17 & 0.2 \\
\hline Benishangul Gumuz & 81 & 1.1 \\
\hline Gambela & 21 & 0.3 \\
\hline Afar & 71 & 0.9 \\
\hline
\end{tabular}

(Continued)
Table I (Continued).

\begin{tabular}{|l|l|l|}
\hline Variables & Frequency (N) & Percent (\%) \\
\hline Addis Ababa & 198 & 2.6 \\
Dire Dawa & 33 & 0.4 \\
Somali & 269 & 3.5 \\
\hline Age at first sexual intercourse & & \\
Before I8 years & 5925 & 78.1 \\
I8 years and above & 1665 & 11.9 \\
\hline
\end{tabular}

Table 2 Obstetrics and Related Characteristics of Women Who Gave Birth in the Five Years Preceding the EDHS 2016, Ethiopia

\begin{tabular}{|c|c|c|}
\hline Variables & Frequency $(\mathbf{N})$ & Percent (\%) \\
\hline \multicolumn{3}{|l|}{ Antenatal care } \\
\hline Yes & 4757 & 62.7 \\
\hline No & 2833 & 37.3 \\
\hline \multicolumn{3}{|l|}{ Distance of health facility } \\
\hline Big problem & 4407 & 58.1 \\
\hline Not big problem & 3183 & 41.9 \\
\hline \multicolumn{3}{|l|}{ Place of delivery } \\
\hline Health institution & 861 & 6.5 \\
\hline Others (Home, on ambulance) & 6729 & 93.5 \\
\hline \multicolumn{3}{|l|}{ Body mass index } \\
\hline Underweight & 1458 & 19.2 \\
\hline Normal & 5423 & 71.4 \\
\hline Overweight & 411 & 5.4 \\
\hline Obesity & 298 & 3.9 \\
\hline \multicolumn{3}{|l|}{ Sex of neonate } \\
\hline Male & 3941 & 51.9 \\
\hline Female & 3649 & 48.1 \\
\hline \multicolumn{3}{|l|}{ Status of pregnancy } \\
\hline Planned & 2016 & 26.6 \\
\hline Unplanned & 5574 & 73.4 \\
\hline \multicolumn{3}{|l|}{ Contraceptive use } \\
\hline Yes & 2699 & 35.6 \\
\hline No & 4891 & 64.4 \\
\hline
\end{tabular}

compared with their counterparts. The odds of experiencing obstetric fistula among women who resided in rural areas were 1.5 times (95\% CI:1.2-5.05) higher compared with women who resided in urban areas (Table 4).

\section{Discussion}

This is the first nationwide demographic and health survey analysis on the prevalence and associated factors of obstetric fistula in Ethiopia. This study revealed that the 
Table 3 Characteristics of Women Who Gave Birth in the Five Years Preceding the EDHS 2016, Ethiopia

\begin{tabular}{|l|l|l|}
\hline Variables & Frequency (N) & Percent (\%) \\
\hline $\begin{array}{l}\text { At what time the problem } \\
\text { happened }\end{array}$ & & \\
During delivery of a live baby & 21 & 65.6 \\
During delivery of a stillbirth & 7 & 21.9 \\
Neither delivering live/ & 4 & 12.5 \\
stillbirth & & \\
\hline $\begin{array}{l}\text { Condition of labor } \\
\text { Normal labor/delivery }\end{array}$ & 8 & \\
Prolonged/very difficult labor & 20 & 28.57 \\
\hline Sought treatment for fistula & & 71.42 \\
Yes & 17 & \\
No & 15 & 53.1 \\
\hline Where the person sought fistula & & 46.9 \\
treatment & & \\
Health facility & 11 & 67.14 \\
Others* (religion \& tradition) & 6 & 42.86 \\
\hline Operation to fix fistula & & 35.3 \\
Yes & 7 & 58.8 \\
No & 10 & \\
\hline Has the leakage stopped & & \\
completely after fixation & & \\
Yes, completely stopped & 4 & \\
No, not completely stopped \\
but reduced & 3 & \\
\hline
\end{tabular}

prevalence of obstetric fistula is $0.42 \%$. History of contraceptive use, distance from the health facility, age at first sexual intercourse, early marriage, and rural residence were the risk factors associated with obstetric fistula. The finding of this study is lower than in India $(23.7 \%)$, and Nigeria $(3.2 \%)$. The discrepancy might be due to the inclusion criteria or the study participants, sample size, socioeconomic status, and the availability of the maternal health-care system of the country. ${ }^{11,14}$

A worldwide systematic review and meta-analysis result showed that the prevalence of obstetric fistula in South Asia (1.2\%), sub-Saharan Africa and South Asia (1.60), Malawi (0.26\%), Nigeria (1.1\%), Kenya (0.44\%), and sub-Saharan Africa (1.57) was in line with these study findings. ${ }^{12,15-17}$ As the WHO has suggested that over 2 million women, mostly from sub-Saharan African and Asian countries, have a fistula, this would suggest that 3 per 1000 women of reproductive age have a fistula, which is considerably lower than our estimate for the Ethiopian demographic and health survey study. ${ }^{13}$
The Uganda Demographic and Health Surveys (DHS) showed that $1-2 \%$ of Ugandan women have symptoms of OF, of whom only $62 \%$ have sought treatment, which is in line with this study finding; of the 32 obstetric fistula patients, $17(51.8 \%)$ have sought treatment. This might be due to the quality of health-care services and accessibility being quite similar. The odds of having obstetric fistula among women who resided in rural areas was 1.5 times higher than that of women who resided in urban areas (AOR $=1.5 ; 95 \%$ CI: $1.2-5.05)$.

Various works of literature show that rural place of residence is the major risk factor for obstetric fistula, as evidenced by studies conducted in Ethiopia, ${ }^{19}$ Zambia, ${ }^{20}$ and West Africa. ${ }^{21}$ The risk of having obstetric fistula was 1.52 times higher among women having early marriage (marriage $<18$ years old) than having marriage after 18 years old $(\mathrm{AOR}=1.52(95 \% \mathrm{CI} ; 1.12-3.5)$. Issues of maternal health everywhere are critical since genderbased violence, harmful practices such as female genital mutilation, and early marriages are all contributing factors to the fistula problem across the world.

Women who were not using contraceptives were 3.43 times more likely to have experience of obstetric fistula than women using any contraceptive after controlling for other variables in the model $(\mathrm{OR}=3.43$; 95\% CI: $1.05-11.21)$. Literatures show that family planning programs can reduce the number of pregnancies in a given population and thus reduce the number of women at risk for pregnancy complications, moreover, obstetric fistula can be prevented through contraception via prevention of unplanned pregnancy.

Women having a big problem in reaching a health facility were 3.7 times more likely to experience obstetric fistula than women with a health facility in close reach $(\mathrm{AOR}=3.7 ; 95 \%$ CI:1.4-10.2). This study finding is consistent with one conducted in Kenya which showed that taking more than 2 hours to reach a health facility was a predisposing factor for obstetric fistula. ${ }^{23}$ In addition, according to the delay model, there are three delays that contribute to obstetrics fistula development: delay in making the decision to seek care; delay in arrival at a health facility; and delay in the provision of adequate care resulting in obstetric fistula. ${ }^{24}$ Distance from healthcare facilities was a determinant factor as playing a role in the delay in seeking of treatment during childbirth. This study advocates nationally representative data, as an advanced sample size can be used to show the burden of the problem. However, this study has a shared crosssectional study design, which may not show a cause and 
Table 4 Bivariable and Multivariable Logistic Regression of Women Who Gave Birth in the Five Years Preceding the EDHS 20I6, Ethiopia

\begin{tabular}{|c|c|c|c|c|c|c|c|}
\hline \multirow[t]{2}{*}{ Variable } & \multicolumn{2}{|c|}{$\begin{array}{l}\text { Experienced of } \\
\text { Obstetric Fistula }\end{array}$} & \multirow[t]{2}{*}{ COR } & \multirow[t]{2}{*}{ AOR } & \multicolumn{3}{|c|}{ Pseudo R Squared measures } \\
\hline & Yes & No & & & Cox and Snell & Nagelkerke & McFadden \\
\hline $\begin{array}{l}\text { Distance from health facility } \\
\text { Big problem } \\
\text { Not big problem }\end{array}$ & $\begin{array}{l}26 \\
6\end{array}$ & $\begin{array}{l}4380 \\
3178\end{array}$ & $\begin{array}{l}3.14(1.26-9.8) \\
1\end{array}$ & $\begin{array}{l}3.7(1.4-10.2) \\
\text { I }\end{array}$ & 0.001 & 0.023 & 0.022 \\
\hline $\begin{array}{l}\text { Contraceptive use } \\
\text { Yes } \\
\text { No }\end{array}$ & $\begin{array}{l}5 \\
27\end{array}$ & $\begin{array}{l}2694 \\
4864\end{array}$ & $\begin{array}{l}\text { I } \\
2.99(1.1-10.4)\end{array}$ & $\begin{array}{l}1 \\
3.43(1.05-11.21)\end{array}$ & 0.001 & 0.019 & 0.018 \\
\hline $\begin{array}{l}\text { Age at first sexual intercourse } \\
\text { Before } 18 \text { years } \\
18 \text { years and above }\end{array}$ & $\begin{array}{l}29 \\
3\end{array}$ & $\begin{array}{l}5896 \\
1662\end{array}$ & $\begin{array}{l}2.7(1.05-10.17) \\
1\end{array}$ & I.4(0.89-9.87) & 0.011 & 0.011 & 0.011 \\
\hline $\begin{array}{l}\text { Age at first marriage } \\
\text { Early marriage } \\
\text { Late marriage }\end{array}$ & $\begin{array}{l}24 \\
8\end{array}$ & $\begin{array}{l}5445 \\
2057\end{array}$ & $\begin{array}{l}1.13(1.03-3.8) \\
1\end{array}$ & $\begin{array}{l}1.52(1.12-3.5) \\
\mathrm{I}\end{array}$ & 0.000 & 0.001 & 0.001 \\
\hline $\begin{array}{l}\text { Antenatal care } \\
\text { Yes } \\
\text { No }\end{array}$ & $\begin{array}{l}22 \\
10\end{array}$ & $\begin{array}{l}4735 \\
2823\end{array}$ & $\begin{array}{l}\text { I } \\
0.76(0.26-2.36)\end{array}$ & $\begin{array}{l}1 \\
0.6(0.2-1.9)\end{array}$ & 0.000 & 0.001 & 0.001 \\
\hline $\begin{array}{l}\text { Residence } \\
\text { Rural } \\
\text { Urban }\end{array}$ & $\begin{array}{l}29 \\
3\end{array}$ & $\begin{array}{l}6592 \\
966\end{array}$ & $\begin{array}{l}\text { I.4(I.2-5.75) } \\
\text { I }\end{array}$ & $\begin{array}{l}\text { I.5(I.2-5.05) } \\
\text { I }\end{array}$ & 0.000 & 0.002 & 0.002 \\
\hline $\begin{array}{l}\text { Place of delivery } \\
\text { Health facility } \\
\text { Others (Home, on ambulance) }\end{array}$ & $\begin{array}{l}7 \\
25\end{array}$ & $\begin{array}{l}855 \\
6704\end{array}$ & $\begin{array}{l}\text { I } \\
0.45(0.2-1.65)\end{array}$ & $\frac{1}{0.3(0.08-1.13)}$ & 0.000 & 0.005 & 0.005 \\
\hline $\begin{array}{l}\text { Status of pregnancy } \\
\text { Planned } \\
\text { Unplanned }\end{array}$ & $\begin{array}{l}20 \\
12\end{array}$ & $\begin{array}{l}5554 \\
2004\end{array}$ & $\begin{array}{l}\text { I } \\
\text { I.66(0.6-4.3) }\end{array}$ & I.52(0.75-5.03) & 0.000 & 0.005 & 0.005 \\
\hline
\end{tabular}

effect relationship. Besides, the effects of the health system, women's knowledge and perceptions towards obstetric fistula, and health-worker factors were no assessed.

\section{Conclusion}

In sub-Saharan Africa and Asian countries, it is conservatively estimated that more than 2 million young women live with untreated obstetric fistula. This study finding revealed that obstetric fistula is directly linked to one of the major causes of maternal mortality due to obstructed labor. Early marriage, distance from the health facility, no history of contraceptive use, and rural residence were the predisposing factors to develop an obstetric fistula. Thus, interventions should focus on creating community awareness regarding early marriage and its consequences, early seeking of health facility visiting, and avoiding unintended pregnancy to minimize the subsequent complications.

\section{Data Sharing Statement}

All the datasets we used for this study are publicly available from the DHS Program website http://dhsprogram.com/data.

\section{Ethics Approval and Consent to Participate}

All the available datasets were obtained from the EDHS website (https://dhsprogram.com/) through registering with the DHS website, so ethical approval was not required. 


\section{Acknowledgment}

We are indebted to the DHS Program for providing us with permission to use the 2016 EDHS data for this analysis.

\section{Author Contributions}

All authors (GG, AW, AG, MB and AD) made a significant contribution to the work reported, whether that is in the conception, study design, execution, acquisition of data, analysis and interpretation, or in all these areas; took part in drafting, revising or critically reviewing the article; gave final approval of the version to be published; have agreed on the journal to which the article has been submitted; and agree to be accountable for all aspects of the work.

\section{Funding}

There is no specific funding for this work.

\section{Disclosure}

The authors declared that they have no competing interests.

\section{References}

1. Tebeu PM, Fomulu JN, Khaddaj S, de Bernis L, Delvaux T, Rochat $\mathrm{CH}$. Risk factors for obstetric fistula: a clinical review. Int Urogynecol J. 2012;23(4):387-394. doi:10.1007/s00192-0111622-x

2. Jokhio AH, Rizvi RM, Rizvi J, MacArthur C. Prevalence of obstetric fistula: a Population-Based Study in rural Pakistan. BJOG. 2014;121 (8):1039-1046. doi:10.1111/1471-0528.12739

3. Muleta M, Hamlin EC, Fantahun M, Kennedy RC, Tafesse B. Health and social problems encountered by treated and untreated obstetric fistula patients in rural Ethiopia. J Obstet Gynaecol Can. 2008;30 (1):44-50. doi:10.1016/S1701-2163(16)32712-8

4. Amodu OC, Salami BO, Richter MS. Obstetric fistula policy in Nigeria: a critical discourse analysis. BMC Pregnancy Childbirth. 2018;18(1):269. doi:10.1186/s12884-018-1907-x

5. Karateke A, Cam C, Ozdemir A, Guney B, Vatansever D, Celik C. Characteristics of obstetric fistulas and the need for a prognostic classification system. Arch Med Sci. 2010;6(2):253. doi:10.5114/ aoms.2010.13904

6. Wall LL, Arrowsmith SD, Briggs ND, Browning A, Lassey A. The obstetric vesicovaginal fistula in the developing world. Obstet Gynecol Surv. 2005;60(7):S3. doi:10.1097/00006254-200507001-00002

7. Browning A, Menber B. Women with obstetric fistula in Ethiopia: a 6month follow up after surgical treatment. BJOG. 2008;115 (12):1564-1569. doi:10.1111/j.1471-0528.2008.01900.x

8. Capes T, Ascher-Walsh C, Abdoulaye I, Brodman M. Obstetric fistula in low and middle income countries. Mount Sinai J Med. 2011;78 (3):352-361. doi:10.1002/msj.20265
9. Donnay F, Ramsey K. Eliminating obstetric fistula: progress in partnerships. Int $J$ Gynaecol Obstet. 2006;94(3):254-261. doi:10.1016/j.ijgo.2006.04.005

10. Balcha WF, Nigussie AA, Beyene FY, Tesfu AA. Awareness and its associated factors of obstetrics fistula among antenatal care attendees in Injibara Town Health Institutions, Awi Zone, North West, Ethiopia, 2019. J Pregnancy. 2020;2020:2020. doi:10.1155/2020/7306108

11. Swain D, Parida SP, Jena SK, Das M, Das H. Prevalence and risk factors of obstetric fistula: implementation of a need-based preventive action plan in a south-eastern rural community of India. $B M C$ Womens Health. 2020;20(1):1-10. doi:10.1186/s12905-020-00906-w

12. Adler AJ, Ronsmans C, Calvert C, Filippi V. Estimating the prevalence of obstetric fistula: a systematic review and meta-analysis. BMC Pregnancy Childbirth. 2013;13(1):1-14. doi:10.1186/14712393-13-1

13. Health E, UNFPA. Obstetric Fistula Needs Assessment Report: Findings from Nine African Countries. New York: UNFPA; 2003.

14. Bello OO, Morhason-Bello IO, Ojengbede OA. Nigeria, a high burden state of obstetric fistula: a contextual analysis of key drivers. Pan Afr Med J. 2020;36:22. doi:10.11604/pamj.2020.36.22.22204

15. Kalilani-Phiri LV, Umar E, Lazaro D, Lunguzi J, Chilungo A. Prevalence ofobstetric fistula in Malawi. Int J Gynaecol Obstet. 2010;109(3):204-208. doi:10.1016/j.ijgo.2009.12.019

16. Mabeya HM. Characteristics of women admitted with obstetric fistula inthe rural hospitals in west Pokot, Kenya. Postgraduate training course inreproductive health 2004; 2004. Available from http:// wwwgfmerch/Medical_education_En/PGC_RH_2004/Obstetric_fis tula_Kenyahtm. Accessed September 6, 2011.

17. Jaiya MA, Aboyeji PA. Obstetric urogenital fistula: the Ilorin experienceNigeria. West Afr J Med. 2004;23(1):7-9. doi:10.4314/ wajm.v23i1.28071

18. den Hollander GC, Janszen EW. Obstetric fistulas in Uganda: scoping review using a determinant of health approach to provide a framework for health policy improvement. BMC Pregnancy Childbirth. 2020;20(1):1-8.

19. Andargie AA, Debu A. Determinants of obstetric Fistula in Ethiopia. Afr Health Sci. 2017;17(3):671-680. doi:10.4314/ahs.v17i3.9

20. Holme A, Breen M, Mac AC. Ob-stetric fistula a study of women managed at the Monze Mission Hospital, Zambia. BJOG. 2007;114 (8):1010-1017. doi:10.1111/j.1471-0528.2007.01353.x

21. Nathan LM, Rochat HC, Bank E, Gringo-rescu B. Obstetric fistula in West Africa: patients' perspectives. Am J Obstet Gynecol. 2008;200 (5):40-42. doi:10.1016/j.ajog.2008.10.014

22. Wall LL. Overcoming Phase 1 delays: the critical component of obstetric fistula prevention programs in resource-poor countries. BMC Pregnancy Childbirth. 2012;12(1):1-13. doi:10.1186/14712393-12-68

23. Thaddeus S, Maine D. Too far to walk: maternal mortality in context. Soc Sci Med. 1994;38(8):1091-1110. doi:10.1016/0277-9536(94) 90226-7

24. Roka ZG, Akech M, Wanzala P, Omolo J, Gitta S, Waiswa P. Factors associated with obstetric fistulae occurrence among patients attending selected hospitals in Kenya, 2010: a Case Control Study. BMC Pregnancy Childbirth. 2013;13(1):1-7. doi:10.1186/1471-2393-13-56

25. Animut M, Mamo A, Abebe L, Berhe MA, Asfaw S, Birhanu Z. The sun keeps rising but darkness surrounds us: a qualitative exploration of the lived experiences of women with obstetric fistula in Ethiopia. BMC Womens Health. 2019;19(1):1-10. doi:10.1186/s12905-0190732-3

26. Semere L, Nour NM. Obstetric fistula: living with incontinence and shame. Rev Obstet Gynecol. 2008;1(4):193. 


\section{Publish your work in this journal}

The International Journal of Women's Health is an international, peerreviewed open-access journal publishing original research, reports, editorials, reviews and commentaries on all aspects of women's healthcare including gynecology, obstetrics, and breast cancer. The manuscript management system is completely online and includes a very quick and fair peer-review system, which is all easy to use. Visit http://www.dovepress.com/testimonials.php to read real quotes from published authors.

Submit your manuscript here: https://www.dovepress.com/international-journal-of-womens-health-journal 